\title{
Enhanced trace element concentrations in tissues of the clam Ruditapes decussatus transplanted to areas influenced by human activities (Ria Formosa, Portugal)
}

\author{
Maria João Botelho ${ }^{1,2}$, Sara T. Costa ${ }^{1}$, Domitília Matias ${ }^{1,2}$, Florbela Soares ${ }^{1}$, \\ Sandra Joaquim ${ }^{1,2}$, Carlos Vale ${ }^{2}$ \\ ${ }^{1}$ IPMA, Portuguese Institute for the Sea and Atmosphere, Rua Alfredo Magalhães Ramalho 6, \\ 1495-006 Lisbon, Portugal. \\ (MJB) (Corresponding author) E-mail: mjbotelho@ipma.pt. ORCID-iD: http://orcid.org/0000-0001-9330-9979 \\ (STC) E-mail: sara.dacosta@ipma.pt. ORCID-iD: http://orcid.org/0000-0002-7786-5876 \\ (DM) E-mail: dmatias@ipma.pt. ORCID-iD: http://orcid.org/0000-0002-2191-7497 \\ (FS) E-mail: fsoares@ipma.pt. ORCID-iD: http://orcid.org/0000-0001-6075-2472 \\ (SJ) E-mail: sandra @ipma.pt. ORCID-iD: http://orcid.org/0000-0002-6324-5908 \\ ${ }^{2}$ CIIMAR, Interdisciplinary Centre of Marine and Environmental Research, University of Porto, Rua dos Bragas 289, \\ 4050-123 Porto, Portugal. \\ (CV) E-mail: carlos.vale@ ciimar.up.pt. ORCID-iD: http://orcid.org/0000-0003-0162-1960
}

\begin{abstract}
Summary: To examine the extent to which human activities near the Ria Formosa coastal lagoon influence the accumulation of trace elements (TE) in Ruditapes decussatus, individuals were transplanted from a natural bank located in the lower lagoon to three sites located in clam growth grounds under the influence of a small city (Faro), a fish farming centre (Olhão) and a site near the lagoon inlet (Lavajo). Concentrations were determined in substrate of the clam grounds and in the digestive gland, gills, mantle plus siphons, and remaining tissues of clams in four periods of the year. These measurements were accomplished with the monthly survey of the gametogenic stages, condition index, proteins, glycogen, total lipids, $\mathrm{pH}$ and osmolarity of hemolymph. Arsenic, $\mathrm{Cu}, \mathrm{Mn}, \mathrm{V}, \mathrm{Cr}$ and $\mathrm{Pb}$ were preferentially linked to the digestive gland, while $\mathrm{Cd}$ was linked to the gills. TE concentrations in the digestive gland and remaining tissues were higher in winter, most likely reflecting additional inputs associated with rain. The lack of disruptions in biological parameters and the prolonged period of spawning and gonad recovery in clams suggest that the current TE availability in the lagoon has a minor influence on the reproductive cycle and hence on clam production.
\end{abstract}

Keywords: trace elements; biological parameters; Ruditapes decussatus; Ria Formosa.

Aumento de la concentración de elementos traza en tejidos de la almeja Ruditapes decussatus trasplantada a zonas influenciadas por actividades humanas (ría Formosa, Portugal)

Resumen: Para examinar en qué medida las actividades humanas cercanas a la laguna costera ría Formosa influyen en la acumulación de elementos traza (ET) en Ruditapes decussatus, se trasplantaron individuos desde un banco natural situado en la parte baja de la laguna a tres sitios localizados en zonas de cultivo de almejas bajo la influencia de una ciudad pequeña (Faro), un centro piscícola (Olhão) y cerca de la entrada de una laguna (Lavajo). Se determinaron las concentraciones de ET en el substrato de locales y en la glándula digestiva, branquias, manto más sifones, y en los tejidos restantes de las almejas en cuatro períodos a lo largo de un año. Estas mediciones fueron realizadas con el estudio mensual de las etapas gametógenas, índice de condición, proteínas, glicóneo, lípidos totales, $\mathrm{pH}$ y osmolaridad de la hemolinfa. $\mathrm{El} \mathrm{As,} \mathrm{Cu}, \mathrm{Mn}, \mathrm{V}, \mathrm{Cr}$ y $\mathrm{Pb}$ fueron relacionados preferencialmente a la glándula digestiva, mientras que el Cd fue a las branquias. La concentración de ET en la glándula digestiva y los tejidos restantes fue más elevada en invierno, probablemente reflejando los aportes adicionales asociados con la lluvia. La falta de alteraciones de los parámetros biológicos, el período prolongado de desove y la recuperación de las gónadas en las almejas sugieren que la disponibilidad actual de ET en la laguna tienen una influencia menor durante el ciclo reproductivo y, por lo tanto, en la producción de almejas.

Palabras clave: elementos traza; parámetros biológicos; Ruditapes decussatus; ría Formosa.

Citation/Como citar este artículo: Botelho M.J., Costa S.T., Matias D., Florbela Soares, Joaquim S., Vale C. 2017. Enhanced trace element concentrations in tissues of the clam Ruditapes decussatus transplanted to areas influenced by human activities (Ria Formosa, Portugal). Sci. Mar. 81(2): 229-239. doi: http://dx.doi.org/10.3989/scimar.04595.13A

Editor: C. Porte.

Received: December 14, 2016. Accepted: March 15, 2017. Published: May 2, 2017.

Copyright: (c) 2017 CSIC. This is an open-access article distributed under the terms of the Creative Commons Attribution (CC-by) Spain 3.0 License. 


\section{INTRODUCTION}

Coastal lagoons are among the most productive ecosystems supporting habitats for wildlife and commercially explored species (Costanza et al. 1997). These services are often at risk due to the increasing stress caused by contaminants from activities related to urbanization, industrialization, intensive agriculture in the watershed, massive tourism, and intensive aquaculture (e.g. Amiard et al. 2006, Cooper et al. 2013). Among numerous contaminants released to the environment, metals and metalloids are a worldwide concern due to their persistence and toxicity (ATSDR 2015). Organisms exposed to trace elements may accumulate them in tissues leading to various inductive responses, such as production of metallothioneins to sequestrate toxic metals (Bebianno and Langston 1993), and triggering antioxidant defence systems to prevent the formation of reactive oxygen species and their deleterious effects (Ivanina et al. 2013, Lushchak 2011). Trace elements may interfere with the variation of physiological parameters related to the organism's wellbeing (Yatoo et al. 2013). In the case of bivalves, several works have reported high consumption of glycogen, lipids and proteins in response to environmental contamination (Hamza-Chaffai 2014, Luna-Acosta et al. 2015), leading to changes in the condition index (Cravo et al. 2012) and eventually in the gametogenesis cycle (Breitwieser et al. 2016, Gauthier-Clerc et al. 2002). According to Mantel and Farmer (1983), metal exposure may alter the fluid ion level in clams, causing the decrease of $\mathrm{Na}^{+}, \mathrm{Cl}^{-}$and $\mathrm{K}^{+}$contents as a compensatory process in the internal osmolarity regulation.

In biomonitoring studies, an important step is to evaluate whether trace element distribution in key organisms is determined by inherent processes, such as those associated with the sexual cycle, as expected at low impacted environments, or is highly influenced by human activities. The objective of this work was to examine whether human activities in Ria Formosa and the surrounding region have a major influence on the trace element partitioning in the clam Ruditapes decussatus produced on inter-tidal flats, superimposed on changes related to metabolic processes. This hypothesis was tested by transplanting clams from a natural bank to three sites: one under the influence of urban activities, one of fish aquaculture earthen ponds, and one near the lagoon inlet, which was used as a reference site. Concentrations of $\mathrm{Zn}, \mathrm{As}, \mathrm{Cu}, \mathrm{Mn}, \mathrm{Ni}, \mathrm{V}, \mathrm{Cr}$, $\mathrm{Pb}$ and $\mathrm{Cd}$ were determined in digestive glands, gills, mantle plus siphons and remaining tissues of the transplanted clams over an annual period. This was accomplished by the survey of gametogenic stages, condition index, proteins, glycogen, total lipids, hemolymph $\mathrm{pH}$ and hemolymph osmolarity. Concentrations of most of these trace elements are reported in previous studies of the area, such as Cortesão et al. (1986), Bebianno and Serafim (2003), and Caetano et al. (2007). Major characteristics of clam ground subtract, including major and trace element contents, were also determined in his study.

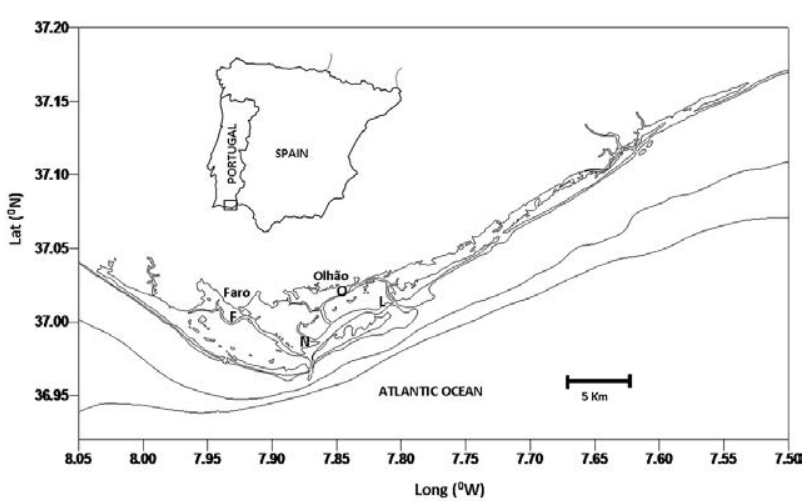

Fig. 1. - Ria Formosa: sampling sites F, O and L for sediments and clam Ruditapes decussatus; natural banks of clams $(\mathrm{N})$, and location of cities of Faro and Olhão.

\section{MATERIALS AND METHODS}

\section{Study area and sampling design}

Ria Formosa is a shallow, meso-tidal coastal lagoon located on the south coast of Portugal (Fig. 1). This lagoon is a paradigmatic example of an ecosystem with ecological and economic importance although it is under stress from human activities and displays alterations of its morphology reflecting its fragility to extreme natural conditions, such as sea storms (Cunha et al. 2005, Guimarães et al. 2012, Vila-Concejo et al. 2002). The lagoon has several channels and a large inter-tidal area covered by sand, muddy sand-flats, and salt marshes (Falcão and Vale 1990). It extends for $55 \mathrm{~km}$ along the coastline and has a maximum width of $6 \mathrm{~km}$ (Newton and Mudge 2003). The hydrodynamics is forced mainly by the semidiurnal tidal regime exchanging water to the sea through several inlets (Nobre et al. 2005). Except in periods of heavy rains, the freshwater input to the lagoon is negligible, salinity remaining approximately 36 all year long (Águas 1985, Falcão and Vale 1990). Spatial distribution of nutrients and chlorophyll $a$ is highly influenced by internal processes, such as sediment-water interactions, and exchanges with the sea (Cravo et al., 2014, Falcão and Vale 1990, Newton et al. 2003). In addition to diffuse sources in the watershed, discharges of domestic effluents and boat traffic increase drastically in summer with tourism (Cravo et al. 2012, Mudge and Bebianno 1997). Several studies have documented the trace element contamination in sediments (Bebianno 1995, Caetano et al. 2002, Cortesão et al. 1986), in water (Caetano et al. 2007, Falcão and Vale 1990) and in bivalves, namely clams (Bebianno and Serafim 2003, Cravo et al. 2012, Serafim and Bebianno 2001). Ria Formosa is traditionally used for the production of the clam R. decussatus, which represents $90 \%$ of the national production of bivalves. The production of $R$. decussatus is $47 \%$ of total aquaculture production in Portugal (DGRM 2013). The decline of clam production in the last two decades has been attributed to a combination of factors, such as clam mortalities probably related to pathologies and less favourable environmental conditions (Matias et al. 2011). 
A field experiment was performed with the clam $R$. decussatus in inter-tidal ground plots. Clams were collected from a natural recruitment area $(\mathrm{N})$ and transplanted to sand squares of $25 \mathrm{~m}^{2}$ with a clam density of $1 \mathrm{~kg} \mathrm{~m}^{-2}$ at the three sites (Fig. 1). Site F is located in a clam growth ground near Faro city and is consequently influenced by urban activities. Site $\mathrm{O}$ is in a clam ground that receives the wastewater of the Aquaculture Research Station (7 ha) through a small tributary that increases its flow in winter in response to precipitation. In contrast to the locations of these inner sites, site $\mathrm{L}$ is positioned in an inter-tidal clam ground of the inlet channel Lavajo that connects the lagoon to the adjacent coastal waters. Transplantation of clams started on 23 November 2010 and sampling ended on 25 October 2011.

\section{Sample preparation}

The upper layer of the clam ground substrate (0-2 $\mathrm{cm}$ ) was collected from sites $\mathrm{F}, \mathrm{O}$ and L (Fig. 1) in November 2010 and March, August and October 2011. Samples were homogenized and separated into three sub-samples kept at $4^{\circ} \mathrm{C}$ for the determination of loss in ignition, grain size, and the following elements: aluminium ( $\mathrm{Al})$, chromium $(\mathrm{Cr})$, zinc $(\mathrm{Zn})$, copper $(\mathrm{Cu})$, nickel $(\mathrm{Ni})$, lead $(\mathrm{Pb})$, arsenic (As), cobalt $(\mathrm{Co})$ and cadmium $(\mathrm{Cd})$. Elements were quantified in sediment samples that had been previously freeze-dried. Transplanted clams with a mean length of $2.8 \pm 0.4$ $\mathrm{cm}$ were collected in February, May and August 2011 from the sites F, O and L and carefully dissected to remove digestive glands, gills, mantle plus siphons, and remaining tissues. Three pools of composite samples $(\mathrm{n}=10$ specimens) were prepared, weighed and frozen at $-20^{\circ} \mathrm{C}$. Samples were freeze-dried, ground and homogenized for determination of $\mathrm{Al}$ and trace elements. Forty clams were collected monthly from each transplanted site and placed in filtered seawater $(0.45 \mu \mathrm{m})$ at $20^{\circ} \mathrm{C}$ in the laboratory for $24 \mathrm{~h}$ to purge their stomachs. Twenty clams were stored at $-20^{\circ} \mathrm{C}$ to determine condition index and gross biochemical composition (proteins, glycogen and total lipids). In another set of 20 individuals, the visceral mass was separated from siphons and gills and fixed in the Davidson solution for $48 \mathrm{~h}$, and then transferred to $70 \%$ ethyl alcohol for storage until histological analysis to evaluate the gametogenic stages. Osmolarity and $\mathrm{pH}$ were determined in the hemolymph collected immediately after sampling from the foot and adductor muscle of ten clams with a $21 \mathrm{G}$ needle and $1-\mathrm{mL}$ syringes. Then, it was centrifuged for $10 \mathrm{~min}\left(4500 \mathrm{~g}, 4^{\circ} \mathrm{C}\right)$, snap-frozen in liquid nitrogen and stored at $-80^{\circ} \mathrm{C}$ until analysis (Gustafson et al. 2005).

\section{Analytical procedures}

\section{Histology}

Each group of 20 individuals was examined histologically to determine the gametogenic stages in specimens of both sexes. Samples were dehydrated with serial dilutions of ethyl alcohol and embedded in paraffin. Thick sections $(6-8 \mu \mathrm{m})$ were cut on a microtome and stained with haematoxylin and eosin. The slides prepared for the histology were examined using a microscope at $40 \times$ magnification and each specimen was assigned to a phase which represented the gonadal state. Clam reproductive maturity was categorized into six phases using a scale development proposed by Delgado and Pérez-Camacho (2005) modified by Matias et al. (2013): phase I, sexual rest; phase II, beginning of gametogenesis; phase III, advanced gametogenesis; phase IV, ripe; phase V, partially spawned; and phase VI, spent. When more than one developmental stage occurred simultaneously within a single individual, the assignment of a phase criteria decision was based upon the condition of the majority of the section.

\section{Condition index}

Condition index (CI) of each clam was calculated by the expression $\mathrm{CI}=$ [dry weight of whole soft tissues $(\mathrm{g}) /$ dry shell weight $(\mathrm{g})] \times 100$ (Walne 1976). Dry weight of whole soft tissues and of shell was determined by the weight difference after oven drying at $80^{\circ} \mathrm{C}$ for $24 \mathrm{~h}$. CI of each sample was expressed by the mean CI calculated for ten individuals.

\section{Biochemical parameters}

Protein, glycogen and total lipid contents were determined in whole soft tissues. Protein was determined using the modified Lowry method (Shakir et al. 1994), glycogen using the anthrone reagent (Viles and Silverman 1949), and total lipids were extracted from fresh homogenized material in chloroform/methanol (Folch et al. 1957) and estimated spectrophotometrically after charring with concentrated sulphuric acid (Marsh and Weinstein 1966). All values are expressed as $\mu \mathrm{g} \mathrm{mg}^{-1}$ of dry weight (dw).

\section{Osmolarity and $\mathrm{pH}$}

Plasma osmolarity (Gustafson et al. 2005) and $\mathrm{pH}$ were analysed directly with a cryo-osmometer and a portable $\mathrm{pH}$ meter, respectively.

\section{Chemical elements}

Approximately $200 \mathrm{mg}$ of clam soft tissues were mineralized according to the method described in Raimundo and Vale (2008): digestion with $\mathrm{HNO}_{3}$ (sp, 65\% $\mathrm{v} / \mathrm{v})$ at $60^{\circ} \mathrm{C}$ for 12 hours and $100^{\circ} \mathrm{C}$ for 1 hour; pursuing the digestion with $\mathrm{H}_{2} \mathrm{O}_{2}\left(\mathrm{sp}, 30 \% \mathrm{v} / \mathrm{v}\right.$ ) at $80^{\circ} \mathrm{C}$ for 1 hour; and dilution of solutions to $45 \mathrm{~mL}$ with ultra-pure water. The mineralization procedure used to determine $\mathrm{Al}$ and trace elements $(\mathrm{Cr}, \mathrm{Zn}, \mathrm{Cu}, \mathrm{Ni}, \mathrm{Pb}, \mathrm{As}, \mathrm{Co}$ and $\mathrm{Cd}$ ) in sediment samples is described in Mil-Homens et al. (2014), and involves the following steps: approximately $0.1 \mathrm{~g}$ of sediment were totally dissolved with a mixture of Aqua Regia ( $\left.\mathrm{HCl}-36 \%: \mathrm{HNO}_{3}-65 \% ; 3: 1\right)$ and $\mathrm{HF}$ at $100^{\circ} \mathrm{C}$ for $1 \mathrm{~h}$; sample solutions were evaporated to near dryness and eluted with $\mathrm{HNO}_{3}$ (double- 
Table 1. - Certified (mean \pm uncertainty) and obtained (mean \pm standard deviation) $\mathrm{Zn}, \mathrm{As}, \mathrm{Cu}, \mathrm{Ni}, \mathrm{Cr}, \mathrm{Pb}, \mathrm{Cd}, \mathrm{Co}, \mathrm{Mn}$ and $\mathrm{V}$ concentrations $\left(\mu \mathrm{g} \mathrm{g}^{-1}\right)$ in the replicates $(\mathrm{n}=3)$ of certified reference materials.

\begin{tabular}{|c|c|c|c|c|c|c|c|c|}
\hline \multirow{2}{*}{ Element } & \multicolumn{2}{|c|}{ MESS-3 } & \multicolumn{2}{|c|}{ PACS-2 } & \multicolumn{2}{|c|}{ DORM-3 } & \multicolumn{2}{|c|}{ TORT-2 } \\
\hline & Certified value & Obtained value & Certified value & Obtained value & Certified value & Obtained value & Certified value & Obtained value \\
\hline$\overline{\mathrm{Zn}}$ & $159 \pm 8$ & $151 \pm 3$ & $364 \pm 23$ & $371 \pm 5$ & $51.3 \pm 3.1$ & $39.7 \pm 2.5$ & $180 \pm 6$ & $161 \pm 7$ \\
\hline As & $21.2 \pm 1.1$ & $19.1 \pm 1.5$ & $26.2 \pm 1.5$ & $24.7 \pm 2.3$ & $6.88 \pm 0.30$ & $6.05 \pm 0.32$ & $21.6 \pm 1.8$ & $19.2 \pm 0.44$ \\
\hline $\mathrm{Cu}$ & $33.9 \pm 1.6$ & $30.6 \pm 2.3$ & $310 \pm 12$ & $302 \pm 16$ & $15.5 \pm 0.63$ & $13.5 \pm 0.98$ & $106 \pm 10$ & $86.2 \pm 4.0$ \\
\hline $\mathrm{Ni}$ & $46.9 \pm 2.2$ & $43.3 \pm 2.5$ & $39.5 \pm 2.3$ & $38.8 \pm 2.5$ & $1.28 \pm 0.24$ & $1.49 \pm 0.18$ & $2.5 \pm 0.19$ & $2.0 \pm 0.24$ \\
\hline $\mathrm{Cr}$ & $105 \pm 4$ & $95 \pm 8$ & $90.7 \pm 4.6$ & $89.1 \pm 1.9$ & $1.89 \pm 0.17$ & $2.16 \pm 0.23$ & $0.77 \pm 0.15$ & $1.1 \pm 0.15$ \\
\hline $\mathrm{Pb}$ & $21.1 \pm 0.7$ & $20.2 \pm 2$ & $183 \pm 8$ & $184 \pm 6$ & $0.395 \pm 0.05$ & $0.449 \pm 0.01$ & $0.35 \pm 0.13$ & $0.29 \pm 0.028$ \\
\hline $\mathrm{Cd}$ & $0.24 \pm 0.01$ & $0.25 \pm 0.03$ & $2.11 \pm 0.15$ & $2.13 \pm 0.087$ & $0.290 \pm 0.020$ & $0.274 \pm 0.004$ & $26.7 \pm 0.6$ & $25.2 \pm 0.1$ \\
\hline Co & $14.4 \pm 2.0$ & $11.6 \pm 0.85$ & $11.5 \pm 0.3$ & $11.3 \pm 0.3$ & - & - & - & - \\
\hline Mn & - & - & - & - & - & - & $13.6 \pm 1.2$ & $10.6 \pm 0.41$ \\
\hline V & - & - & - & - & - & - & $1.64 \pm 0.19$ & $1.76 \pm 0.17$ \\
\hline
\end{tabular}

distilled) and ultra-pure water; and sample solutions were diluted to $50 \mathrm{~mL}$ with ultra-pure water.

Chemical elements in sediment and clam samples were quantified in a quadrupole ICP-MS (Thermo Elemental, X-series) equipped with a Peltier Impact bead spray chamber and a concentric Meinhard nebulizer (Caetano et al. 2013, Raimundo et al. 2013). Three procedural blanks were prepared using the same analytical procedure and reagents, and included within each batch of samples. Procedural blanks accounted for less than $1 \%$ of the total element in the samples. Detection limits were $0.20 \%$ for $\mathrm{Al}, 0.0009 \mu \mathrm{g} \mathrm{g} \mathrm{g}^{-1}$ for $\mathrm{Cd}, 0.0010 \mu \mathrm{g}$ $\mathrm{g}^{-1}$ for $\mathrm{Ni}, 0.0015 \mu \mathrm{g} \mathrm{g}^{-1}$ for $\mathrm{Cu}, 0.0016 \mu \mathrm{g} \mathrm{g}^{-1}$ for $\mathrm{Mn}$, $0.0019 \mu \mathrm{g} \mathrm{g}^{-1}$ for $\mathrm{Cr}, 0.0020 \mu \mathrm{g} \mathrm{g}^{-1}$ for $\mathrm{Co}, 0.0030 \mu \mathrm{g}$ $\mathrm{g}^{-1}$ for $\mathrm{V}, 0.0032 \mu \mathrm{g} \mathrm{g}^{-1}$ for $\mathrm{Zn}, 0.0088 \mu \mathrm{g} \mathrm{g}^{-1}$ for $\mathrm{Pb}$ and $0.74 \mu \mathrm{g} \mathrm{g}^{-1}$ for As. Quality control of the results was obtained through the use of the certified reference materials CRM PACS-2 and MESS-3 (marine sediment) for sediment samples, and the CRM TORT-2 (lobster hepatopancreas) and DORM-3 (fish protein) for biological samples. The accuracy was checked by analysing three replicate samples of each CRM. In general, the results indicate good agreement between certified and obtained values (Table 1). Repeatability values in terms of relative standard deviation for CRM measurements $(n=3)$ ranged from $1 \%$ to $14 \%$.

\section{Loss on ignition and grain size}

Loss on ignition of sediments was calculated from weight loss after ignition at $450^{\circ} \mathrm{C}$ for 3 hours (Falcão and Vale 1998). Sediment grain size analysis was undertaken by the standard sieving method. Grain size parameters were computed by the Folk and Ward (Folk and Ward 1957) method using the Grangraf program.

\section{Statistical analyses}

Statistical analyses were performed using SigmaPlot13.0 (Systat Software Inc.®) for Windows with a pvalue of 0.05 . Whenever the pre-requisites of normality and homogeneity of variances were fulfilled, an ANOVA test was performed to determine the significance of the differences found between sites or sampling dates for the sediment characteristics, biological parameters and trace elements in clam tissues. Principal component analyses (PCAs) were performed using Statistica 8.0 (StatSoft $\AA$ ). Conventional descriptive multivariate analyses were used to summarize high-dimensionality
Table 2. - Coarse fraction ( $>63 \mu \mathrm{m}, \mathrm{CF}$ ), loss on ignition (LOI, \%) $\mathrm{Al}$ content $(\%)$, and concentrations $\left(\mu \mathrm{g} \mathrm{g}^{-1} \mathrm{dw}\right)$ of $\mathrm{Cr}, \mathrm{Zn}, \mathrm{Cu}, \mathrm{Ni}$, $\mathrm{Pb}, \mathrm{As}, \mathrm{Co}$ and $\mathrm{Cd}$ in sediments collected at sites $\mathrm{F}, \mathrm{O}$ and $\mathrm{L}$ in November 2010, March, August and October 2011; mean values $( \pm \mathrm{SD} ; \mathrm{n}=3)$; different letters $(\mathrm{a}, \mathrm{b}, \mathrm{c})$ correspond to values significantly $(\mathrm{p}<0.05)$ different among sites.

\begin{tabular}{lccc}
\hline & $\mathrm{F}$ & $\mathrm{O}$ & $\mathrm{L}$ \\
\hline $\mathrm{CF}$ & $87 \pm 3.8 \mathrm{a}$ & $88 \pm 4.3 \mathrm{ab}$ & $100 \pm 0.07 \mathrm{~b}$ \\
$\mathrm{LOI}$ & $1.1 \pm 0.36 \mathrm{ab}$ & $1.4 \pm 0.48 \mathrm{a}$ & $0.55 \pm 0.10 \mathrm{~b}$ \\
$\mathrm{Al}$ & $1.8 \pm 0.34 \mathrm{a}$ & $1.4 \pm 0.28 \mathrm{a}$ & $0.88 \pm 0.18 \mathrm{~b}$ \\
$\mathrm{Cr}$ & $19 \pm 1.8 \mathrm{a}$ & $13 \pm 1.6 \mathrm{~b}$ & $30 \pm 1.5 \mathrm{c}$ \\
$\mathrm{Zn}$ & $13 \pm 1.9 \mathrm{a}$ & $15 \pm 4.1 \mathrm{a}$ & $4.0 \pm 0.79 \mathrm{~b}$ \\
$\mathrm{Cu}$ & $4.2 \pm 0.61 \mathrm{a}$ & $6.6 \pm 0.78 \mathrm{~b}$ & $1.1 \pm 0.24 \mathrm{c}$ \\
$\mathrm{Ni}$ & $3.6 \pm 0.67 \mathrm{a}$ & $2.5 \pm 0.64 \mathrm{~b}$ & $1.3 \pm 0.10 \mathrm{c}$ \\
$\mathrm{Pb}$ & $4.3 \pm 0.68 \mathrm{a}$ & $4.1 \pm 0.83 \mathrm{a}$ & $2.7 \pm 0.30 \mathrm{~b}$ \\
$\mathrm{As}$ & $3.0 \pm 0.71 \mathrm{a}$ & $1.7 \pm 0.20 \mathrm{a}$ & $1.7 \pm 0.010 \mathrm{a}$ \\
$\mathrm{Co}$ & $1.0 \pm 0.19 \mathrm{a}$ & $0.8 \pm 0.24 \mathrm{a}$ & $0.80 \pm 0.23 \mathrm{a}$ \\
$\mathrm{Cd}$ & $0.035 \pm 0.0045 \mathrm{a}$ & $0.015 \pm 0.0042 \mathrm{~b}$ & $0.0091 \pm 0.0017 \mathrm{~b}$ \\
\hline
\end{tabular}

data in a simpler two-dimensional space (Abdi and Williams 2010). The aim was to interpret major trends of similarities between sites, clam tissues and sampling dates, using correlation-based element variables. Sample matrix of the whole dataset was composed of 45 tissue samples and 9 descriptors (As, $\mathrm{Cd}, \mathrm{Cr}, \mathrm{Cu}, \mathrm{Mn}$, $\mathrm{Ni}, \mathrm{Pb}, \mathrm{V}$ and $\mathrm{Zn}$ ). PCA was also applied to digestive samples and remaining tissue samples.

\section{RESULTS}

\section{Sediment characteristics}

The major characteristics of the sediment samples collected in the inter-tidal ground plots $\mathrm{F}, \mathrm{O}$ and $\mathrm{L}$ are presented in Table 2. The sediments consisted of sand $(>63 \mu \mathrm{m})$ with a small fraction of fine particles. The proportion of coarser particles (mean $\pm \mathrm{SD})$ ranged from $87 \% \pm 3.8 \%$ (site F) to $100 \% \pm 0.07 \%$ (site L). Accordingly, $\mathrm{Al}$ content was low in sediments from the three sites, although it was significantly $(\mathrm{p}<0.05)$ higher at sites $\mathrm{F}$ and $\mathrm{O}$ than at site L. Loss on ignition varied from $0.50 \%$ to $2.0 \%$ and was significantly $(\mathrm{p}<0.05)$ higher at site $\mathrm{O}$ than at site $\mathrm{L}$.

Due to the narrow variation of $\mathrm{Al}$ content and its low values, trace element concentrations in sediments from the three sampling sites were compared without normalization with $\mathrm{Al}$ commonly used recurrently to minimize differences related to grain size (Windom et al. 1989). Significant differences of trace element concentrations among sites are presented in Table 2. Copper concentration $\left(\mu \mathrm{g} \mathrm{g}^{-1}\right)$ was significantly $(\mathrm{p}<0.05)$ 


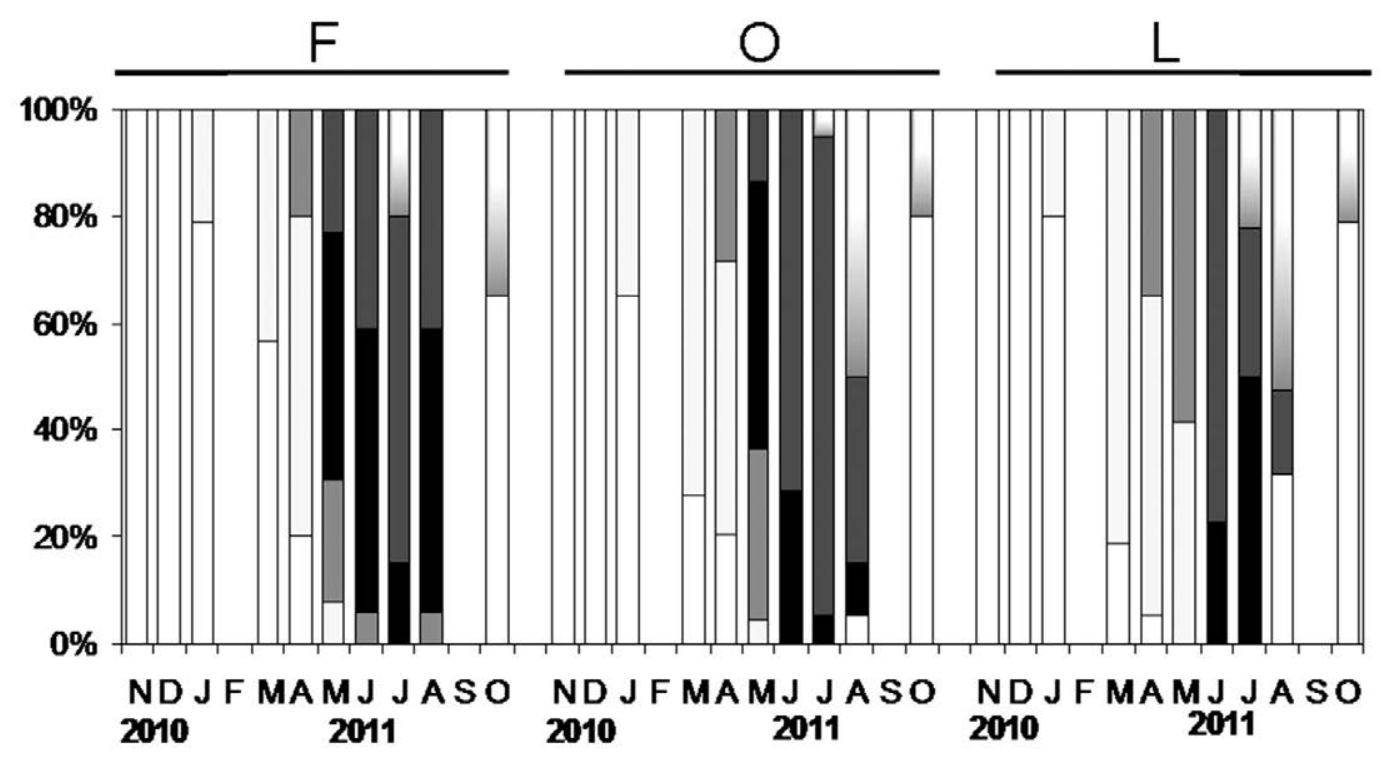

I $\square$ II $\square$ III $\square$ IV $\square$ V $\square \mathrm{V}$

Fig. 2. - Maturation stages (phase I, sexual rest; phase II, gametogenesis beginning; phase III, advanced gametogenesis; phase IV, ripe; phase $\mathrm{V}$, partially spawned; and phase VI, spent) of the clam Ruditapes decussatus ( $\mathrm{n}=20)$ transplanted to sites F, O and L; data over an annual cycle.

higher at site $\mathrm{O}(6.6 \pm 0.78)$ than at sites $\mathrm{F}(4.2 \pm 0.61)$ and $\mathrm{L}(1.1 \pm 0.24)$. A different distribution was encountered for $\mathrm{Cd}$ and was significantly $(\mathrm{p}<0.05)$ higher at site $\mathrm{F}(0.035 \pm 0.0045)$ than at sites $\mathrm{O}(0.015 \pm 0.0042)$ and $\mathrm{L}(0.0091 \pm 0.0017)$. Chromium in sands from site $\mathrm{L}(30 \pm 1.5)$ displayed significantly $(\mathrm{p}<0.05)$ higher values than in sands from sites $\mathrm{F}(19 \pm 1.8)$ and $\mathrm{O}(13 \pm 1.6)$.

\section{Biological parameters}

Maturation stages over an annual cycle of $R$. decussatus transplanted to sites F, O and L are presented in Figure 2. The histological phase II, indicating the beginning of the gametogenesis, was first observed in January at the three sites. The histological phase V, indicating partially spawned development, started in May (sites F and O) and June (site L), and was highly marked in July and August at the three sites. During the spawning season (May to August), microscopic observation of gonads revealed simultaneous spawning (phase IV) and partial spawning (phase V). This observation was clearer in clams from the inner sites $\mathrm{F}$ and $\mathrm{O}$. Most of the clams had already spawned in October and remained inactive thereafter.

Table 3 gives the monthly mean values and SD of the condition index, proteins, glycogen and total lipids of clams from each transplanted site over the annual survey cycle. From January to July (site F) or to August (sites $\mathrm{O}$ and $\mathrm{L}$ ), which corresponds to the reproductive period, CI varied between 6 and 11, and then remained within the interval 4-7 until October (sites F and L). Considering all sampling dates, no significant $(\mathrm{p}<0.05)$ differences were found among the three sites. Clams transplanted to sites F, O and $\mathrm{L}$ in November showed lower protein content $\left(102 \pm 26 \mu \mathrm{g} \mathrm{mg}^{-1}\right)$ than those transplanted in subsequent months, reaching a maximum ranging from $378 \pm 50 \mu \mathrm{g} \mathrm{mg}^{-1}$ (site F) to $436 \pm 73$ $\mu \mathrm{g} \mathrm{mg}^{-1}$ (site L). Clams from site $\mathrm{O}$ showed significantly $(\mathrm{p}<0.05)$ higher protein contents than those from sites $\mathrm{F}$ and $\mathrm{L}$. Mean glycogen varied between $9.0 \pm 5.0$ and $19 \pm 7.1 \mu \mathrm{g} \mathrm{mg}^{-1}$ (site F), 5.9 \pm 1.1 and $16 \pm 7.6 \mu \mathrm{g}$ $\mathrm{mg}^{-1}$ (site $\mathrm{O}$ ), and $6.5 \pm 1.4$ and $25 \pm 11 \mu \mathrm{g} \mathrm{mg}^{-1}$ (site L),

Table 3. - Mean values $( \pm \mathrm{SD} ; \mathrm{n}=10)$ of condition index $(\mathrm{CI})$, proteins, glycogen and total lipids $\left(\mu \mathrm{g} \mathrm{mg}^{-1} \mathrm{dw}\right)$ of Ruditapes decussatus collected at sites F, O and L in November, December 2010, January, March, April, May, June, July, August and October 2011; different letters $(\mathrm{a}, \mathrm{b}, \mathrm{c})$ correspond to significant $(\mathrm{p}<0.05)$ differences among sites, considering all sampling dates.

\begin{tabular}{|c|c|c|c|c|c|c|c|c|c|c|c|c|}
\hline \multirow{2}{*}{ Parameter } & \multirow{2}{*}{ Site } & \multicolumn{2}{|c|}{2010} & \multicolumn{8}{|c|}{2011} & \multirow{2}{*}{$\begin{array}{l}\text { Differences } \\
\text { among sites }\end{array}$} \\
\hline & & Nov & Dec & Jan & Mar & Apr & May & Jun & Jul & Aug & Oct & \\
\hline \multirow[t]{3}{*}{ CI } & $\mathrm{F}$ & $7.8 \pm 2.1$ & $10 \pm 3.7$ & $8.2 \pm 3.4$ & & $8.3 \pm 1.3$ & 11.7 & $12 \pm 2.9$ & $8.0 \pm 1.1$ & $4.6 \pm 1.1$ & $4.5 \pm 1.1$ & $\mathrm{a}$ \\
\hline & $\mathrm{O}$ & $7.8 \pm 2.1$ & $5.8 \pm 1.2$ & $7.3 \pm 1.6$ & & $6.6 \pm 2.2$ & $7.6 \pm 3.8$ & $9.6 \pm 1.4$ & $9.9 \pm 5.2$ & $11 \pm 6.9$ & $4.2 \pm .9 .0$ & $\mathrm{a}$ \\
\hline & $\mathrm{L}$ & $7.8 \pm 2.1$ & & $10 \pm 3.6$ & $10 \pm 3.6$ & $7.8 \pm 4.7$ & 6.7 & $8.8 \pm 5.8$ & $6.6 \pm 0.9$ & $7.7 \pm 1.1$ & $6.9 \pm 1.6$ & $\mathrm{a}$ \\
\hline \multirow[t]{3}{*}{ Proteins } & $\mathrm{F}$ & $102 \pm 26$ & $27 \overline{5 \pm} 62$ & $205 \pm 35$ & \multirow[t]{2}{*}{ 1. - } & $181 \pm 28$ & $139 \pm 54$ & $150 \pm 23$ & $162 \pm 18$ & $378 \pm 50$ & $104 \pm 27$ & $\mathrm{a}$ \\
\hline & $\mathrm{O}$ & $102 \pm 26$ & $335 \pm 63$ & $366 \pm 76$ & & $269 \pm 65$ & $200 \pm 68$ & $338 \pm 55$ & $309 \pm 90$ & $424 \pm 146$ & $317 \pm 82$ & b \\
\hline & $\mathrm{L}$ & $102 \pm 26$ & & $111 \pm 25$ & $385 \pm 89$ & $301 \pm 76$ & $183 \pm 37$ & $72 \pm 16$ & $436 \pm 73$ & $168 \pm 30$ & $125 \pm 44$ & $\mathrm{a}$ \\
\hline \multirow[t]{3}{*}{ Glycogen } & $\mathrm{F}$ & $14 \pm 10$ & $17 \pm 10$ & $9.0 \pm 5.0$ & \multirow[t]{2}{*}{ - } & $11 \pm 4.0$ & $16 \pm 4.0$ & $12 \pm 4.8$ & $19 \pm 7.1$ & $12 \pm 5.6$ & $14 \pm 11$ & $\mathrm{a}$ \\
\hline & $\mathrm{O}$ & $14 \pm 10$ & $11 \pm 4.5$ & $14 \pm 5.4$ & & $16 \pm 7.6$ & $16 \pm 6.8$ & $5.9 \pm 1.1$ & $11 \pm 9.2$ & $8.1 \pm 1.6$ & $9.3 \pm 1.3$ & b \\
\hline & $\mathrm{L}$ & $14 \pm 10$ & & $22 \pm 11$ & $6.5 \pm 1.4$ & $10 \pm 3.5$ & $25 \pm 11$ & $21 \pm 9.6$ & $7.8 \pm 2.6$ & $22 \pm 8.0$ & $13 \pm 4.3$ & $\mathrm{c}$ \\
\hline \multirow[t]{3}{*}{ Total lipids } & $\mathrm{F}$ & $31 \pm 10$ & $17 \pm 7.1$ & $79 \pm 21$ & \multirow[t]{2}{*}{ 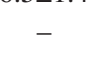 } & $84 \pm 20$ & $77 \pm 18$ & $47 \pm 20$ & $45 \pm 12$ & $58 \pm 18$ & $43 \pm 15$ & $\mathrm{a}$ \\
\hline & $\mathrm{O}$ & $31 \pm 10$ & $31 \pm 10$ & $61 \pm 22$ & & $49 \pm 17$ & $71 \pm 20$ & $61 \pm 19$ & $72 \pm 30$ & $49 \pm 10$ & $49 \pm 10$ & $\mathrm{a}$ \\
\hline & $\mathrm{L}$ & $31 \pm 10$ & - & $27 \pm 9.7$ & $84 \pm 22$ & $73 \pm 17$ & $78 \pm 29$ & $90 \pm 38$ & $66 \pm 20$ & $104 \pm 47$ & $62 \pm 16$ & b \\
\hline
\end{tabular}




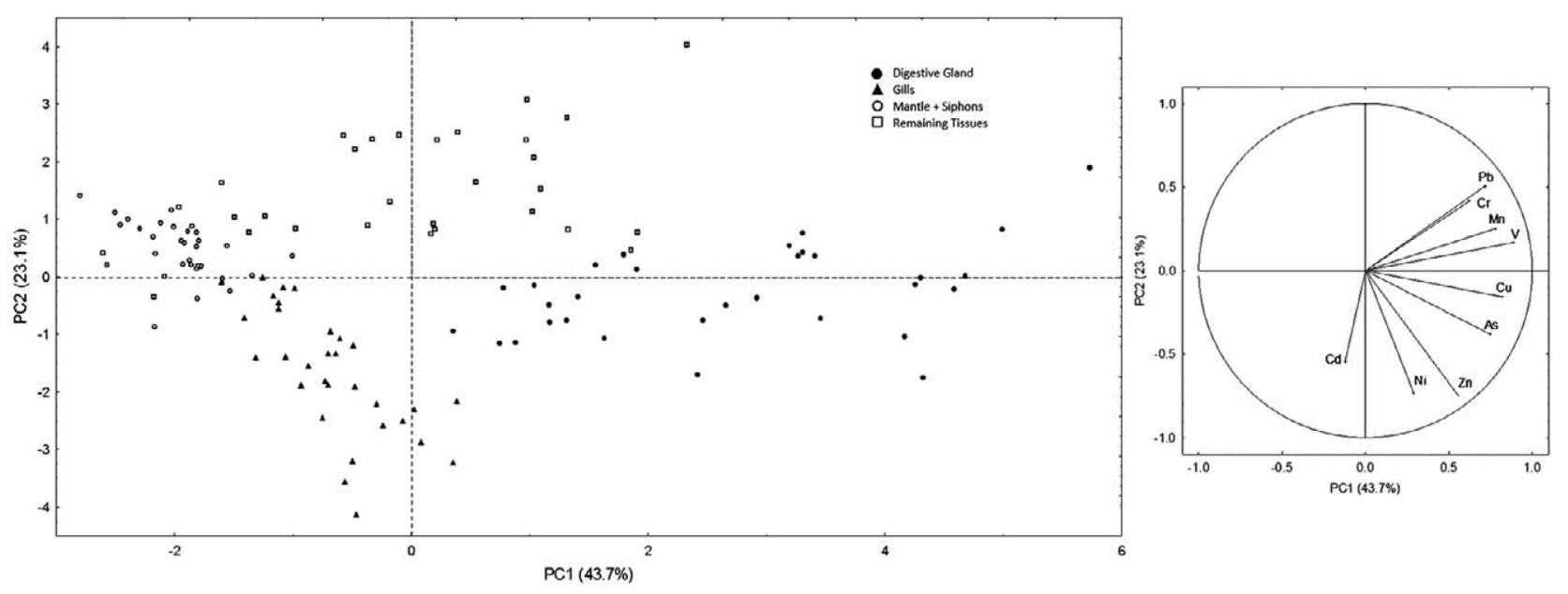

Fig. 3. - Illustration of the principal component analysis (PCA) based on element ( $\mathrm{Zn}, \mathrm{As}, \mathrm{Cu}, \mathrm{Mn}, \mathrm{Ni}, \mathrm{V}, \mathrm{Cr}, \mathrm{Pb}$ and $\mathrm{Cd}$ ) concentrations in clams Ruditapes decussatus, applied to the whole dataset (four clam tissues or parts, three sites and four sampling dates). PC1=43.7\% and $\mathrm{PC} 2=23.1 \%$. V, Cu, Mn, As and $\mathrm{Pb}$ are associated with PC1, and $\mathrm{Zn}$ and $\mathrm{Ni}$ are associated with PC2 (factor coordinates $>|0.7|$ ).
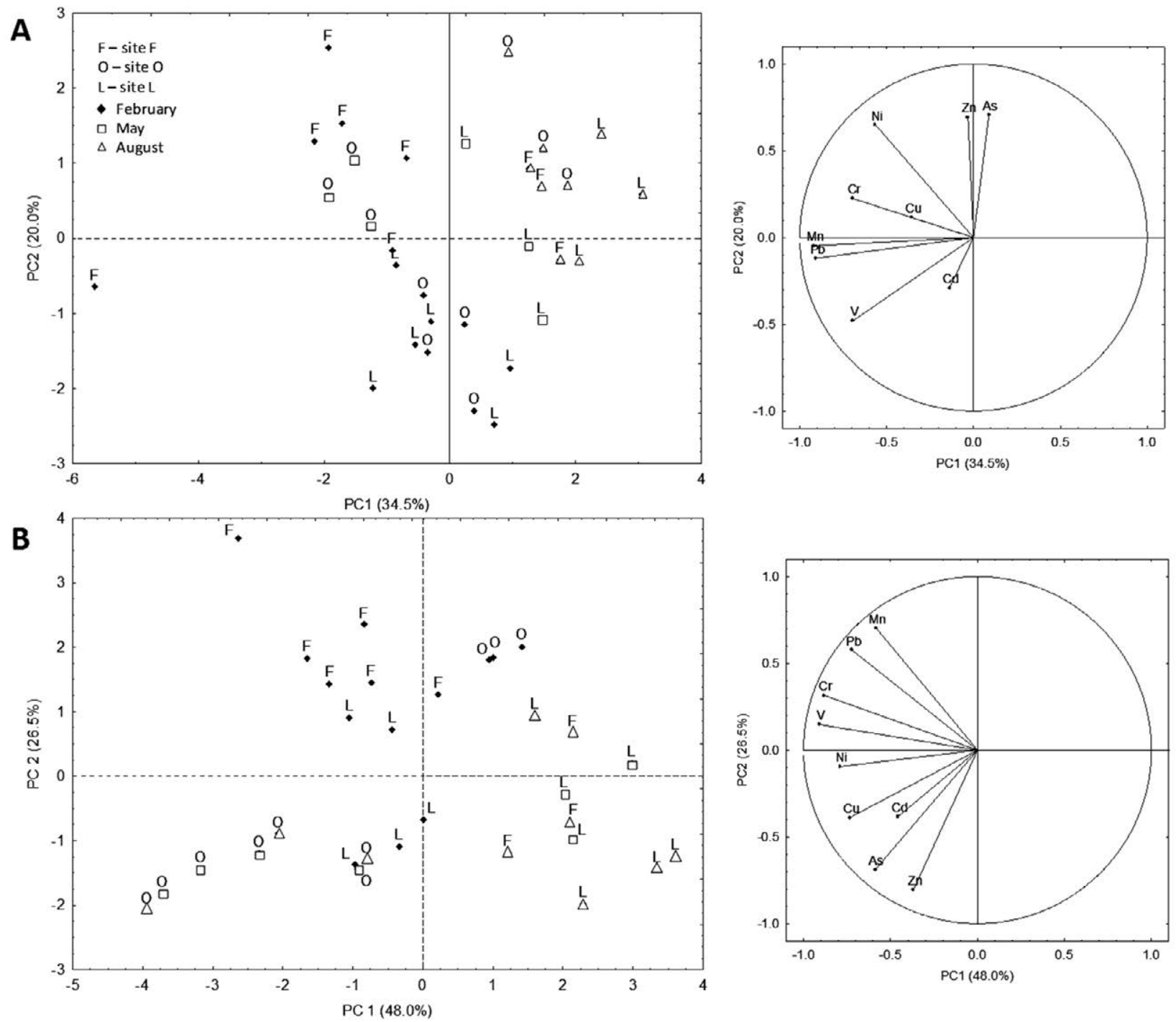

Fig. 4. - Illustration of the principal component analysis (PCA) based on element $(\mathrm{Zn}, \mathrm{As}, \mathrm{Cu}, \mathrm{Mn}, \mathrm{Ni}, \mathrm{V}, \mathrm{Cr}, \mathrm{Pb}$ and $\mathrm{Cd}$ ) concentrations of digestive gland (A) and remaining tissues (B) of the clam Ruditapes decussatus from sites F, $\mathrm{O}$ and $\mathrm{L}$ at four sampling dates. For digestive gland $(\mathrm{PC} 1=34.5 \%$ and $\mathrm{PC} 2=20.0 \%$ ), $\mathrm{Mn}, \mathrm{Pb}$ and $\mathrm{Cr}$ are associated with $\mathrm{PC} 1$, and As is associated with $\mathrm{PC} 2$ (factor coordinates $>|0.7|$ ). For remaining tissues $(\mathrm{PC} 1=48.0 \%$ and $\mathrm{PC} 2=26.5 \%), \mathrm{V}, \mathrm{Cr}, \mathrm{Ni}, \mathrm{Cu}$ and $\mathrm{Pb}$ are associated with $\mathrm{PC} 1$, and $\mathrm{Zn}$ and $\mathrm{Mn}$ are associated with $\mathrm{PC} 2$ (factor coordinates $>|0.7|$ ). 
Table 4. - Concentrations ( $\mu \mathrm{g} \mathrm{g} \mathrm{g}^{-1} \mathrm{dw}$ ) of $\mathrm{Zn}, \mathrm{As}, \mathrm{Cu}, \mathrm{Mn}, \mathrm{Ni}, \mathrm{V}, \mathrm{Cr}, \mathrm{Pb}$ and $\mathrm{Cd}$ in digestive gland (DG), gills (G), mantle plus siphons (M+S) and remaining tissues (RT) of clams Ruditapes decussatus collected at sites F, O and L in November, February, May and August 2011; mean $\pm \mathrm{SD}(\mathrm{n}=3)$; different letters $(\mathrm{a}, \mathrm{b}, \mathrm{c})$ correspond to significant $(\mathrm{p}<0.05)$ differences among sites, considering all sampling dates.

\begin{tabular}{|c|c|c|c|c|c|c|c|c|c|c|c|}
\hline & & & & & & & & & & & \\
\hline & & Nov & Feb & May & Aug & & Nov & Feb & May & Aug & \\
\hline $\mathrm{Zn}$ & $\mathrm{F}$ & $81 \pm 6.4$ & $96 \pm 5.8$ & - & $88 \pm 5.2$ & $\mathrm{a}$ & $69 \pm 1.7$ & $79 \pm 3.6$ & - & $88 \pm 6.1$ & $\mathrm{a}$ \\
\hline & $\mathrm{O}$ & $81 \pm 6.4$ & $89 \pm 4.3$ & $92 \pm 0.047$ & $90 \pm 8.1$ & $\mathrm{a}$ & $69 \pm 1.7$ & $93 \pm 10.9$ & $106 \pm 6.9$ & $81 \pm 3.1$ & $a b$ \\
\hline & $\mathrm{L}$ & $81 \pm 6.4$ & $85 \pm 4.6$ & $100 \pm 13$ & $99 \pm 6.4$ & $\mathrm{a}$ & $69 \pm 1.7$ & $96 \pm 6.8$ & $94 \pm 4.3$ & $93 \pm 3.2$ & $\mathrm{~b}$ \\
\hline As & $\mathrm{F}$ & $64 \pm 5.3$ & $49 \pm 4.7$ & - & $47 \pm 1.6$ & a & $37 \pm 4.2$ & $25 \pm 1.7$ & - & $36 \pm 0.90$ & $\mathrm{a}$ \\
\hline & $\mathrm{O}$ & $64 \pm 5.3$ & $39 \pm 5.0$ & $54 \pm 0.94$ & $55 \pm 1.7$ & $\mathrm{a}$ & $37 \pm 4.2$ & $25 \pm 1.6$ & $36 \pm 0.67$ & $39 \pm 2.2$ & $\mathrm{a}$ \\
\hline & $\mathrm{L}$ & $64 \pm 5.3$ & $44 \pm 3.6$ & $55 \pm 3.1$ & $56 \pm 2.4$ & $\mathrm{a}$ & $37 \pm 4.2$ & $35 \pm 3.4$ & $25 \pm 2.3$ & $34 \pm 1.0$ & $\mathrm{a}$ \\
\hline $\mathrm{Cu}$ & $\mathrm{F}$ & $14 \pm 2.7$ & $26 \pm 3.6$ & - & $17 \pm 0.35$ & $\mathrm{a}$ & $7.1 \pm 0.82$ & $8.0 \pm 0.24$ & - & $6.6 \pm 0.13$ & $\mathrm{a}$ \\
\hline & $\mathrm{O}$ & $14 \pm 2.7$ & $33 \pm 1.8$ & $35 \pm 0.24$ & $35 \pm 4.4$ & b & $7.1 \pm 0.82$ & $8.3 \pm 0.43$ & $8.3 \pm 0.88$ & $10 \pm 0.24$ & $\mathrm{~b}$ \\
\hline & $\mathrm{L}$ & $14 \pm 2.7$ & $24 \pm 3.6$ & $29 \pm 4.4$ & $13 \pm 0.83$ & a & $7.1 \pm 0.82$ & $9.3 \pm 0.79$ & $9.6 \pm 1.3$ & $7.0 \pm 1.1$ & $\mathrm{a}$ \\
\hline Mn & $\mathrm{F}$ & $6.1 \pm 0.89$ & $12 \pm 1.2$ & - & $5.8 \pm 0.53$ & $\mathrm{a}$ & $3.8 \pm 0.45$ & $5.9 \pm 0.15$ & - & $5.3 \pm 0.17$ & $\mathrm{a}$ \\
\hline & $\mathrm{O}$ & $6.1 \pm 0.89$ & $9.9 \pm 0.54$ & $17 \pm 1.0$ & $5.3 \pm 0.50$ & $\mathrm{a}$ & $3.8 \pm 0.45$ & $5.6 \pm 0.33$ & $8.3 \pm 0.36$ & $5.6 \pm 0.24$ & $\mathrm{a}$ \\
\hline & $\mathrm{L}$ & $6.1 \pm 0.89$ & $10 \pm 3.7$ & $7.4 \pm 1.0$ & $3.7 \pm 0.49$ & a & $3.8 \pm 0.45$ & $5.6 \pm 0.86$ & $6.8 \pm 0.59$ & $4.0 \pm 0.15$ & $\mathrm{a}$ \\
\hline $\mathrm{Ni}$ & $\mathrm{F}$ & $2.5 \pm 0.17$ & $4.2 \pm 0.89$ & - & $3.3 \pm 0.50$ & $\mathrm{a}$ & $3.4 \pm 0.12$ & $2.4 \pm 0.57$ & - & $7.2 \pm 0.19$ & $\mathrm{a}$ \\
\hline & $\mathrm{O}$ & $2.5 \pm 0.17$ & $2.5 \pm 0.53$ & $3.2 \pm 0.54$ & $3.3 \pm 0.56$ & $a b$ & $3.4 \pm 0.12$ & $2.4 \pm 0.46$ & $5.8 \pm 0.73$ & $3.2 \pm 0.19$ & $\mathrm{a}$ \\
\hline & $\mathrm{L}$ & $2.5 \pm 0.17$ & $2.1 \pm 0.23$ & $2.4 \pm 0.31$ & $1.9 \pm 0.32$ & $\mathrm{~b}$ & $3.4 \pm 0.12$ & $2.9 \pm 0.74$ & $4.3 \pm 0.61$ & $6.0 \pm 0.72$ & $\mathrm{a}$ \\
\hline V & $\mathrm{F}$ & $2.4 \pm 0.40$ & $6.1 \pm 0.60$ & - & $3.4 \pm 0.076$ & $\mathrm{a}$ & $1.1 \pm 0.23$ & $1.3 \pm 0.15$ & - & $1.5 \pm 0.10$ & $\mathrm{a}$ \\
\hline & $\mathrm{O}$ & $2.4 \pm 0.40$ & $6.0 \pm 0.66$ & $4.7 \pm 0.67$ & $2.9 \pm 0.30$ & $\mathrm{a}$ & $1.1 \pm 0.23$ & $1.5 \pm 0.15$ & $1.4 \pm 0.22$ & $1.4 \pm 0.051$ & $\mathrm{a}$ \\
\hline & $\mathrm{L}$ & $2.4 \pm 0.40$ & $7.1 \pm 0.52$ & $4.1 \pm 0.63$ & $4.1 \pm 0.41$ & $\mathrm{a}$ & $1.1 \pm 0.23$ & $1.5 \pm 0.50$ & $1.9 \pm 0.49$ & $2.3 \pm 0.25$ & $\mathrm{a}$ \\
\hline $\mathrm{Cr}$ & $\mathrm{F}$ & $2.1 \pm 0.068$ & $3.3 \pm 1.1$ & - & $1.6 \pm 0.26$ & a & $1.4 \pm 0.35$ & $1.0 \pm 0.26$ & - & $1.0 \pm 0.15$ & $\mathrm{a}$ \\
\hline & $\mathrm{O}$ & $2.1 \pm 0.073$ & $0.88 \pm 0.12$ & $1.0 \pm 0.84$ & $1.2 \pm 0.05$ & $\mathrm{~b}$ & $1.4 \pm 0.35$ & $0.72 \pm 0.38$ & $1.0 \pm 0.045$ & $0.83 \pm 0.062$ & $\mathrm{a}$ \\
\hline & $\mathrm{L}$ & $2.1 \pm 0.072$ & $1.6 \pm 0.36$ & $1.4 \pm 0.22$ & $1.0 \pm 0.082$ & a & $1.4 \pm 0.35$ & $0.82 \pm 0.32$ & $1.0 \pm 0.21$ & $0.96 \pm 0.12$ & $\mathrm{a}$ \\
\hline $\mathrm{Pb}$ & $\mathrm{F}$ & $0.80 \pm 0.014$ & $1.2 \pm 0.64$ & - & $0.45 \pm 0.021$ & $\mathrm{a}$ & $0.47 \pm 0.084$ & $0.30 \pm 0.079$ & - & $0.25 \pm 0.056$ & $\mathrm{a}$ \\
\hline & $\mathrm{O}$ & $0.80 \pm 0.014$ & $0.85 \pm 0.10$ & $1.7 \pm 0.20$ & $0.46 \pm 0.022$ & a & $0.47 \pm 0.084$ & $0.24 \pm 0.06$ & $0.48 \pm 0.15$ & $0.26 \pm 0.044$ & $\mathrm{a}$ \\
\hline & $\mathrm{L}$ & $0.80 \pm 0.014$ & $0.83 \pm 0.24$ & $0.59 \pm 0.11$ & $0.21 \pm 0.08$ & $\mathrm{a}$ & $0.47 \pm 0.084$ & $0.30 \pm 0.05$ & $0.47 \pm 0.15$ & $0.43 \pm 0.03$ & $\mathrm{a}$ \\
\hline $\mathrm{Cd}$ & $\mathrm{F}$ & $0.19 \pm 0.079$ & $0.21 \pm 0.030$ & - & $0.10 \pm 0.012$ & $\mathrm{a}$ & $0.55 \pm 0.079$ & $0.22 \pm 0.061$ & - & $0.56 \pm 0.12$ & $\mathrm{a}$ \\
\hline & $\mathrm{O}$ & $0.19 \pm 0.079$ & $0.27 \pm 0.031$ & $0.16 \pm 0.018$ & $0.11 \pm 0.012$ & $\mathrm{a}$ & $0.55 \pm 0.079$ & $0.26 \pm 0.072$ & $0.40 \pm 0.021$ & $0.39 \pm 0.063$ & $\mathrm{a}$ \\
\hline & $\mathrm{L}$ & $0.19 \pm 0.079$ & $0.19 \pm 0.03$ & $0.13 \pm 0.01$ & $0.15 \pm 0.04$ & $\mathrm{a}$ & $0.55 \pm 0.079$ & $0.37 \pm 0.09$ & $0.51 \pm 0.10$ & $0.26 \pm 0.01$ & $\mathrm{a}$ \\
\hline & & & & & & & & & & & \\
\hline & & Nov & Feb & May & Aug & & Nov & Feb & May & Ago & \\
\hline $\mathrm{Zn}$ & $\mathrm{F}$ & $44 \pm 2.0$ & $50 \pm 1.8$ & - & $53 \pm 2.9$ & $\mathrm{a}$ & $40 \pm 1.7$ & $49 \pm 3.7$ & - & $57 \pm 8.3$ & $\mathrm{a}$ \\
\hline & $\mathrm{O}$ & $44 \pm 2.0$ & $50 \pm 6.2$ & $64 \pm 0.31$ & $51 \pm 1.9$ & $a$ & $40 \pm 1.7$ & $47 \pm 2.3$ & $74 \pm 8.6$ & $74 \pm 10.6$ & $\mathrm{~b}$ \\
\hline & $\mathrm{L}$ & $44 \pm 2.0$ & $55 \pm 2.1$ & $64 \pm 1.4$ & $58 \pm 2.0$ & a & $40 \pm 1.7$ & $56 \pm 5.8$ & $66 \pm 7.4$ & $61 \pm 6.8$ & $\mathrm{ab}$ \\
\hline As & $\mathrm{F}$ & $25 \pm 0.71$ & $20 \pm 1.8$ & - & $31 \pm 1.4$ & $\mathrm{a}$ & $27 \pm 2.2$ & $25 \pm 3.4$ & - & $26 \pm 6.4$ & $\mathrm{a}$ \\
\hline & $\mathrm{O}$ & $25 \pm 0.71$ & $17 \pm 2.3$ & $25 \pm 1.0$ & $32 \pm 1.6$ & $\mathrm{a}$ & $27 \pm 2.2$ & $18 \pm 1.6$ & $35 \pm 1.6$ & $35 \pm 2.1$ & $\mathrm{a}$ \\
\hline & $\mathrm{L}$ & $25 \pm 0.71$ & $25 \pm 1.6$ & $22 \pm 0.21$ & $28 \pm 2.0$ & $\mathrm{a}$ & $27 \pm 2.2$ & $29 \pm 2.7$ & $21 \pm 3.5$ & $26 \pm 0.91$ & $\mathrm{a}$ \\
\hline $\mathrm{Cu}$ & $\mathrm{F}$ & $12 \pm 1.2$ & $4.6 \pm 0.17$ & - & $7.3 \pm 0.12$ & a & $5.0 \pm 0.19$ & $5.9 \pm 0.53$ & - & $5.5 \pm 0.73$ & $\mathrm{a}$ \\
\hline & $\mathrm{O}$ & $12 \pm 1.2$ & $5.8 \pm 1.1$ & $4.5 \pm 0.46$ & $4.7 \pm 0.53$ & $\mathrm{~b}$ & $5.0 \pm 0.19$ & $6.2 \pm 0.52$ & $10 \pm 0.84$ & $10 \pm 1.0$ & $\mathrm{~b}$ \\
\hline & $\mathrm{L}$ & $12 \pm 1.2$ & $11 \pm 2.6$ & $6.5 \pm 1.1$ & $6.4 \pm 0.37$ & $\mathrm{a}$ & $5.0 \pm 0.19$ & $9.5 \pm 2.0$ & $4.7 \pm 0.88$ & $4.2 \pm 0.36$ & $\mathrm{a}$ \\
\hline Mn & $\mathrm{F}$ & $3.5 \pm 0.21$ & $5.4 \pm 0.62$ & - & $4.7 \pm 0.87$ & $\mathrm{a}$ & $2.3 \pm 0.39$ & $10 \pm 1.5$ & - & $3.6 \pm 0.39$ & $\mathrm{a}$ \\
\hline & $\mathrm{O}$ & $3.5 \pm 0.21$ & $5.5 \pm 0.81$ & $6.8 \pm 1.2$ & $4.7 \pm 0.29$ & $\mathrm{a}$ & $2.3 \pm 0.39$ & $9.4 \pm 0.72$ & $6.6 \pm 0.93$ & $6.6 \pm 1.1$ & $\mathrm{a}$ \\
\hline & $\mathrm{L}$ & $3.5 \pm 0.21$ & $5.2 \pm 0.57$ & $5.9 \pm 0.40$ & $3.7 \pm 0.52$ & a & $2.3 \pm 0.39$ & $8.9 \pm 3.1$ & $4.2 \pm 0.61$ & $1.4 \pm 0.40$ & $\mathrm{a}$ \\
\hline $\mathrm{Ni}$ & $\mathrm{F}$ & $2.0 \pm 0.53$ & $2.1 \pm 0.70$ & - & $2.5 \pm 0.42$ & a & $0.91 \pm 0.15$ & $2.1 \pm 0.16$ & - & $1.7 \pm 0.19$ & $\mathrm{a}$ \\
\hline & $\mathrm{O}$ & $2.0 \pm 0.53$ & $1.1 \pm 0.081$ & $2.8 \pm 0.051$ & $1.7 \pm 0.16$ & $\mathrm{a}$ & $0.91 \pm 0.15$ & $1.4 \pm 0.15$ & $2.3 \pm 0.39$ & $2.1 \pm 0.35$ & $\mathrm{a}$ \\
\hline & $\mathrm{L}$ & $2.0 \pm 0.53$ & $1.3 \pm 0.20$ & $2.1 \pm 0.15$ & $2.7 \pm 0.32$ & a & $0.91 \pm 0.15$ & $1.4 \pm 0.27$ & $1.4 \pm 0.15$ & $1.4 \pm 0.33$ & $\mathrm{a}$ \\
\hline V & $\mathrm{F}$ & $0.85 \pm 0.18$ & $0.98 \pm 0.16$ & - & $1.1 \pm 0.19$ & $\mathrm{a}$ & $0.93 \pm 0.25$ & $3.8 \pm 0.92$ & - & $2.3 \pm 0.10$ & $\mathrm{a}$ \\
\hline & $\mathrm{O}$ & $0.85 \pm 0.18$ & $1.0 \pm 0.20$ & $1.1 \pm 0.44$ & $1.3 \pm 0.26$ & a & $0.93 \pm 0.25$ & $2.4 \pm 0.071$ & $3.9 \pm 0.53$ & $3.7 \pm 0.58$ & $\mathrm{a}$ \\
\hline & $\mathrm{L}$ & $0.85 \pm 0.18$ & $0.86 \pm 0.19$ & $1.2 \pm 0.10$ & $1.5 \pm 0.045$ & a & $0.93 \pm 0.25$ & $2.8 \pm 0.61$ & $2.3 \pm 0.19$ & $1.7 \pm 0.15$ & $\mathrm{a}$ \\
\hline $\mathrm{Cr}$ & $\mathrm{F}$ & $2.0 \pm 1.1$ & $1.1 \pm 0.39$ & - & $0.69 \pm 0.14$ & $\mathrm{a}$ & $0.88 \pm 0.085$ & $3.0 \pm 0.69$ & $\begin{array}{c}2.0-10 \\
-\end{array}$ & $1.6 \pm 0.18$ & $\mathrm{a}$ \\
\hline & $\mathrm{O}$ & $2.0 \pm 1.1$ & $0.48 \pm 0.12$ & $0.74 \pm 0.24$ & $0.62 \pm 0.077$ & $\mathrm{a}$ & $0.88 \pm 0.085$ & $1.6 \pm 0.065$ & $2.7 \pm 0.39$ & $2.7 \pm 0.45$ & $\mathrm{a}$ \\
\hline & $\mathrm{L}$ & $2.0 \pm 1.1$ & $0.63 \pm 0.061$ & $0.59 \pm 0.044$ & $0.67 \pm 0.081$ & $\mathrm{a}$ & $0.88 \pm 0.085$ & $1.7 \pm 0.28$ & $1.2 \pm 0.097$ & $0.62 \pm 0.076$ & $\mathrm{~b}$ \\
\hline $\mathrm{Pb}$ & $\mathrm{F}$ & $0.31 \pm 0.059$ & $0.24 \pm 0.061$ & - & $0.20 \pm 0.040$ & $\mathrm{a}$ & $0.45 \pm 0.018$ & $1.4 \pm 0.28$ & - & $0.40 \pm 0.061$ & $\mathrm{ab}$ \\
\hline & $\mathrm{O}$ & $0.31 \pm 0.059$ & $0.23 \pm 0.084$ & $0.44 \pm 0.24$ & $0.21 \pm 0.042$ & a & $0.45 \pm 0.018$ & $1.3 \pm 0.13$ & $1.2 \pm 0.19$ & $1.2 \pm 0.23$ & a \\
\hline & $\mathrm{L}$ & $0.31 \pm 0.059$ & $0.27 \pm 0.08$ & $0.22 \pm 0.03$ & $0.32 \pm 0.10$ & $\mathrm{a}$ & $0.45 \pm 0.018$ & $1.1 \pm 0.47$ & $0.42 \pm 0.07$ & $0.12 \pm 0.04$ & $\mathrm{~b}$ \\
\hline $\mathrm{Cd}$ & $\mathrm{F}$ & $0.10 \pm 0.052$ & $0.21 \pm 0.053$ & - & $0.30 \pm 0.031$ & a & $0.13 \pm 0.048$ & $0.15 \pm 0.044$ & - & $0.12 \pm 0.002$ & $\mathrm{a}$ \\
\hline & $\mathrm{O}$ & $0.10 \pm 0.051$ & $0.18 \pm 0.041$ & $0.32 \pm 0.086$ & $0.10 \pm 0.041$ & $\mathrm{a}$ & $0.13 \pm 0.048$ & $0.22 \pm 0.038$ & $0.31 \pm 0.0044$ & $0.29 \pm 0.11$ & $\mathrm{~b}$ \\
\hline & $\mathrm{L}$ & $0.10 \pm 0.05$ & $0.24 \pm 0.02$ & $0.21 \pm 0.03$ & $0.18 \pm 0.05$ & a & $0.13 \pm 0.048$ & $0.29 \pm 0.10$ & $0.14 \pm 0.03$ & $0.24 \pm 0.05$ & $\mathrm{ab}$ \\
\hline
\end{tabular}

differing $(\mathrm{p}<0.05)$ significantly among the sites. Mean total lipids were statistically $(\mathrm{p}<0.05)$ higher atsite $\mathrm{L}$ $\left(27 \pm 9.7\right.$ to $\left.104 \pm 47 \mu \mathrm{g} \mathrm{mg}^{-1}\right)$ than at sites $\mathrm{F}(17 \pm 7.1$ to $\left.84 \pm 20 \mu \mathrm{g} \mathrm{mg}^{-1}\right)$ and $\mathrm{O}\left(31 \pm 10\right.$ and $\left.72 \pm 30 \mu \mathrm{g} \mathrm{mg}^{-1}\right)$.

Hemolymph osmolarity of clams from the three sites varied within a narrow interval (mean values of between 1.0 and $1.2 \mathrm{mOs} \mathrm{mgg}^{-1}$ ) over the annual surveyed period. Mean $\mathrm{pH}$ values of clam hemolymph ranged from 7.6 to 8.2 , and no significant ( $\mathrm{p}>0.05)$ differences were observed among the three sites. Clams from sites $\mathrm{F}$ and $\mathrm{L}$ exhibited significantly $(\mathrm{p}<0.05)$ lower $\mathrm{pH}$ from January to September and from May to July, respectively. A less clear variation was found at site $\mathrm{O}$, and $\mathrm{pH}$ was only significantly higher $(\mathrm{p}<0.05)$ in November.

\section{Partitioning of trace elements in clam tissues}

Table 4 gives the mean concentrations $( \pm \mathrm{SD})$ of $\mathrm{Zn}$, As, $\mathrm{Cu}, \mathrm{Mn}, \mathrm{Ni}, \mathrm{V}, \mathrm{Cr}, \mathrm{Pb}$ and $\mathrm{Cd}$ in digestive gland, gills, mantle plus siphons, and remaining tissues of the clams from the recruitment area $(\mathrm{N})$ collected in 
November and of the transplanted clams collected in February, May and August 2011 from sites F, O and L. Significant differences among sites in trace elements of each clam tissue are marked in Table 4. Remaining tissues displayed differences in more elements $(\mathrm{Zn}, \mathrm{Cu}$, $\mathrm{Cr}, \mathrm{Pb}$ and $\mathrm{Cd})$ than digestive glands $(\mathrm{Cu}, \mathrm{Ni}, \mathrm{Cr})$. Gills and mantle plus siphons showed differences only for $\mathrm{Zn}$ and $\mathrm{Cu}$, respectively. In those ten statistical differences, eight enhanced concentrations were observed at site $\mathrm{O}$, while only five were observed at sites $\mathrm{F}$ and $\mathrm{L}$.

In order to have a better integration of trace element partitioning among the four clam parts/tissues, a PCA was applied to the whole dataset (Fig. 3, PC1=43.7\% and $\mathrm{PC} 2=23.1 \%$ ). Samples of the four analysed tissues were generally projected in different quadrants of the plan PC1-PC2; the digestive gland was projected closer to the trace elements and the mantle plus siphons far from these descriptors. Arsenic, $\mathrm{Cu}, \mathrm{Mn}, \mathrm{V}, \mathrm{Cr}$ and $\mathrm{Pb}$ were significantly $(p<0.05)$ higher in digestive gland than in gills. Cadmium was the exception, being more abundant in gills. Zinc, As, $\mathrm{Cu}, \mathrm{Mn}, \mathrm{Ni}$ and $\mathrm{V}$ were significantly $(p<0.05)$ higher in the digestive gland than in the remaining tissues. Another two PCAs were applied separately to digestive gland (Fig. 4A, PC1=34.5\% and $\mathrm{PC} 2=20.0 \%$ ) and to remaining tissues (Fig. 4B, $\mathrm{PC} 1=48.0 \%$ and $\mathrm{PC} 2=26.5 \%$ ). The analysis of gills and mantle plus siphon data are not presented due to the lower variance obtained ( $\mathrm{PC} 1+\mathrm{PC} 2<50 \%)$. The digestive gland plot shows a clear difference between February and May/August, because all February samples are closer to the trace element projections, while May and August samples are represented in quadrants II and III. This dichotomy between winter and late spring/summer was not observed at site $\mathrm{O}$, because May samples are represented near the winter samples. The remaining tissues plot also shows a similar separation between winter and late spring/summer. In addition to this temporal variation, samples collected in May and August at site $\mathrm{O}$ are projected separated from samples of the other sites and associated with $\mathrm{Ni}, \mathrm{Cu}, \mathrm{As}$ and $\mathrm{Zn}$.

\section{DISCUSSION}

\section{Trace element inputs as recorded by sediment composition}

The elemental composition of estuarine and coastal sediments has long been used to identify possible sources of contamination because of the high affinity of trace elements to particles, namely those with a large specific area and covered by organic matter films (Libes 1992). Despite the sandy nature of the substrates (87-100\% sand) the almost negligible proportion of fine particles at site $\mathrm{L}$ appears to explain the lower concentrations of $\mathrm{Zn}, \mathrm{Cu}, \mathrm{Ni}, \mathrm{Pb}$ and $\mathrm{Cd}$ in comparison with sites $\mathrm{F}$ and O. Conversely, the enhancement of $\mathrm{Cr}$ in sands of site $\mathrm{L}$ was most likely due to natural variation related to the lithology, as observed in sandy beach nourishment in other areas of Portugal (Vale, unpublished data). Other factors might account for the slight differences observed at sites $\mathrm{O}$ and $\mathrm{F}$ (Table 2$)$. The significantly $(\mathrm{p}<0.05)$ higher $\mathrm{Cu}$ concentrations in the substrate of site $\mathrm{O}$ in comparison with sites $\mathrm{F}$ and $\mathrm{L}$ may be interpreted as the influence of localized sources of contamination. Most likely, wastes of food artificially enriched with $\mathrm{Cu}$ that is supplied daily to fish produced in the Aquaculture Station located near site $\mathrm{O}$ is partially retained in the lagoon sediments localized nearby. In addition to the regular supply of food, copper sulphate is added occasionally to the aquaculture tanks to eliminate fish parasites that develop mainly in spring, which involves a pulse release of $\mathrm{Cu}$ to the ecosystem. The possible influence of a small tributary draining agriculture fields that ends in the area should also be considered. Due to the torrential precipitation regime, discharges may occur during short periods in winter (Falcão and Vale 1990). However, freshwater discharge into the lagoon should not have been dramatic in the year studied because osmolarity in clams, which is a parameter sensitive to salinity, did not differ among individuals from the three transplanted sites. The enhanced $\mathrm{Cu}$ values found in the present study is in agreement with previous studies in Ria Formosa showing higher $\mathrm{Cu} / \mathrm{Al}$ ratios in sediments near the site O (Caetano et al. 2002, Cortesão et al. 1986). Enhanced concentrations of $\mathrm{Cd}$ and $\mathrm{Ni}$ at site $\mathrm{F}$ in comparison with sites $\mathrm{O}$ and $\mathrm{L}$ probably result from human activities related to Faro city, whose population increases pronouncedly in summer due to tourism (Cravo et al. 2012).

\section{Comparison of trace element concentrations in clams with past studies}

Copper, $\mathrm{Zn}$ and $\mathrm{Cd}$ concentrations measured in gills and digestive gland of $R$. decussates in the present work were lower than the values reported by Serafim and Bebianno (2001) and Bebianno and Serafim (2003) $\mathrm{Cu}$, and $\mathrm{Zn}$ was followed in different tissues (gills, digestive gland, and remaining tissues for the same species from Ria Formosa. Cadmium concentrations in this current work $\left(0.10-0.56 \mu \mathrm{g} \mathrm{g}^{-1}\right)$ were one order of magnitude lower than the values reported by Serafim and Bebianno (2001) $\left(1.4 \pm 0.19 \mu \mathrm{g} \mathrm{g}^{-1}\right)$ and far below the limit recommended for human consumption, $5 \mu \mathrm{g}$ $\mathrm{g}^{-1}$ dry weight (obtained by the conversion of $1 \mu \mathrm{g} \mathrm{g}^{-1}$ wet weight, assuming $80 \%$ as the mean percentage of water in clam flesh) (EC 2001). This decrease suggests a lower availability of this element in food or water over a period that exceeds one decade. Most likely, the reduction of anthropogenic inputs to Ria Formosa contributed to that difference (Cravo et al. 2012). Copper concentrations showed a less marked decrease in comparison with previous studies, and large variations were encountered among the sampling periods and sites (Table 4). Values of $\mathrm{Zn}$ observed in the present work (81-99 $\mu \mathrm{g} \mathrm{g}^{-1}$ ) are comparable to those reported by Serafim and Bebianno (2001) $\left(98 \pm 8.6 \mu \mathrm{g} \mathrm{g}^{-1}\right)$, possibly reflecting the metabolic regulation of $\mathrm{Zn}$ concentrations in bivalves (e.g. Bryan et al. 1979).

\section{Temporal and spatial variations of trace elements in clam tissues}

The similar size and condition index of clams at the three transplanted sites are in favour of comparable 
filtration rates and hence trace element concentrations (Reinfelder et al. 1998). Nevertheless, trace elements in clam tissues, particularly $\mathrm{Cu}$ and $\mathrm{Cr}$, displayed statistical differences $(\mathrm{p}<0.05)$ among the three sites (Table 4). Spatial differences were observed more recurrently in remaining tissues and digestive gland. Spatial availability of trace elements in water and food is a plausible cause for the observed variation in digestive gland concentrations. For example, enhanced values of $\mathrm{Cu}$ in site $\mathrm{O}$ may result from aquaculture practices, which is in line with the sediment composition. Concordance between substrate and clam was less clear for other elements, such as $\mathrm{Cr}$ and $\mathrm{Cd}$.

Filtration rate may also have changed in clams of the three sites due to its sensitivity to contaminant exposure. Bioturbation in clam production grounds contributes to the release of trace elements and nutrients from sediments (Falcão et al. 2006). However, bioturbation is not expected to differ considerably among the transplanted sites because clam density and mortality along the experiments were similar. Despite the renewal of large water volume during spring tides, which promotes a vigorous mixing of water and particles inside the lagoon (Falcão et al. 2006), the PCA of the digestive gland data suggests higher concentrations of most elements in February, particularly at site F. Enhanced values were also observed for remaining tissues in February, which emphasizes the importance of diffusive sources in winter for the accumulation of trace elements by clams. Indeed, the precipitation regime in the region was marked by episodic periods of heavy precipitation (Lima et al. 2013, Soares et al. 2015) and consequent runoff from the city and agriculture fields. The increase inhuman population and leisure activities in summer may have led to higher availability of trace elements in Ria Formosa (Cravo et al. 2012). It may also be hypothesized that internal fluxes of trace elements contribute to the increase in their availability in warmer periods. However, the results obtained suggest the predominance of the rain effect in winter. Previous works have shown that nutrient fluxes from sediments increase with temperature, as well as phytoplankton biomass (Falcão and Vale 1998). In confined areas of the lagoon, dissolved oxygen in the water column tends to be consumed during the night, decreasing to under saturated values. The seasonal decrease of $\mathrm{pH}$ in clam hemolymph, which may be attributed to less oxygenation of the water (McFarland et al. 2011), is in line with the reduction of dissolved oxygen during the night (Falcão and Vale 1998) and consequently the internal input of trace metals to the water column.

Despite the presence of trace elements in the ingested food, the affinity of most determined elements with the digestive gland may be followed by mechanisms that facilitate their retention in this tissue. The sequestration of the elements may be enhanced by the induction of metallothioneins if they are present above a threshold value (Bebianno and Serafim 2003). Cadmium appears to be linked with gills and at a lower level with digestive gland (Fig. 3), which may be influenced by the higher stability of Cd chloro-complexes in seawater (Simões et al. 1981). In addition to the pas- sage of dissolved $\mathrm{Cd}$ through gills during filtration, the presence of metallothioneins in that organ (Bebianno et al. 1994) may also contribute to the retention of $\mathrm{Cd}$.

\section{Reproductive cycle of $\boldsymbol{R}$. decussatus}

The reproductive cycle of $R$. decussatus observed in the present work is in agreement with previous studies on this species at Ria Formosa (Matias et al. 2013, Pacheco et al. 1989). The cycle was characterized by the onset of gametogenesis in January followed by the rapid development of gametes (Fig. 2). Clams reached the highest sexual maturity in May-June (sites F and O) and in June-July (site L). In late spring/summer, condition index and total lipid content remained high, decreasing sharply as rest stage was observed. This change was better observed in clams transplanted to sites $\mathrm{F}$ and $\mathrm{O}$. The spawning was expanded throughout summer until early autumn, clams ensuring a consistent supply of gametes. Indeed, histological analyses showed simultaneously gonias, maturing gametocytes and variable proportions of fully matured gametes in some individuals. The co-occurrence of spawning and gonad recovery (phase $\mathrm{V}$ ) during a long period of the year, concomitantly with nutrient storage and consumption, pointed to high reproductive effort of clams with a high capacity for gonadal regeneration. The continuous supply of gametes mirrors an advantageous strategy of this bivalve species (Matias et al. 2013).

\section{Interaction of accumulated trace elements with the reproductive cycle}

Variations in reproductive output of bivalve molluscs are highly sensitive to environmental perturbations (Weinberg et al. 1997). In particular, accumulated contaminants in bivalves could deplete energy reserves that were initially intended for growth and reproduction (Capuzzo et al. 1988). Under stressful circumstances, energy reserves are allocated to defence mechanisms, so animals living in contaminated areas often show poor tissue condition and retarded growth (Nicholson and Lam 2005). The period of spawning and gonad recovery found in clams transplanted to the inner sites $\mathrm{F}$ and $\mathrm{O}$ (May-October) was longer than in clams of site L (July-October) located in the inlet channel. Probably, the accumulated trace elements have negligible effects on the gametogenesis of $R$. decussatus, even in inner areas of the lagoon that may be affected by localized or diffuse sources of contamination. The successive production of gametes and spawning seems to obscure a trace element pattern during the sexual maturity period. In fact, the PCA indicate dissimilarities between samples of May and August and trace element projections (Figs 3 and 4). However, condition index and total lipids of clams after spawning were better at site $\mathrm{L}$ than at sites $\mathrm{F}$ and $\mathrm{O}$.

These results indicate that trace element partitioning in $R$. decussatus produced in extended inter-tidal flats of Ria Formosa are influenced by environmental changes in winter, most likely associated with rain and diffuse sources. Despite the massive tourism in spring 
and summer, and the consequent increase of domestic effluent discharges, trace element concentrations in clam tissues are low, presumably influenced by the long period of production of gametes and spawning.

\section{ACKNOWLEDGEMENTS}

This work was part of the project QUASUS - Environmental quality and sustainability of biologic resources in Ria Formosa - financed by Sociedade Polis Litoral Ria Formosa. We are grateful to three anonymous reviewers for helping to improve the manuscript. We also thank the colleagues J. Raimundo, P. Brito, A. C. Almeida, F. Catarina and A.M. Matias for their cooperation.

\section{REFERENCES}

Abdi H., Williams L.J. 2010. Principal component analysis. Wiley Interdiscip. Rev. Comput. Stat. 2: 433-459. https://doi.org/10.1002/wics.101

Águas M.P.N. 1985. Simulação da circulação hidrodinâmica na Ria Formosa. Sist. lagunares do Algarve. Semin. Comemorativo do Dia Mund. do Ambiente.

Amiard J.C., Amiard-Triquet C., Barka S., et al. 2006. Metallothioneins in aquatic invertebrates: Their role in metal detoxification and their use as biomarkers. Aquat. Toxicol. 76: 160-202. https://doi.org/10.1016/j.aquatox.2005.08.015

ATSDR 2015.The priority list of hazardous substances that will be the candidates for Toxicological profiles [WWW Document]. Accessed 20/06/2016 at http://www.atsdr.cdc.gov/SPL/index.html

Bebianno M.J. 1995. Effects of pollutants in the Ria Formosa Lagoon, Portugal. Sci. Total Environ. 171: 107-115. https://doi.org/10.1016/0048-9697(95)04672-9

Bebianno M.J., Langston W.J. 1993. Turnover rate of metallothionein and cadmium in Mytilus edulis. Biometals 6: 239-244. https://doi.org/10.1007/BF00187762

Bebianno M.J., Serafim M.A. 2003. Variation of metal and metallothionein concentrations in a natural population of Ruditapes decussatus. Arch. Environ. Contam. Toxicol. 44: 53-66. https://doi.org/10.1007/s00244-002-2004-7

Bebianno M.J., Serafim M.A.P., Rita M.F. 1994. Involvement of metallothionein in cadmium accumulation and elimination in the clam Ruditapes decussata. Bull. Environ. Contam. Toxicol. 53: 726-732. https://doi.org/10.1007/BF00196946

Breitwieser M., Viricel A., Graber M., et al. 2016. Short-term and long-term biological effects of chronic chemical contamination on natural populations of a marine bivalve. PLoS One 11: e0150184 https://doi.org/10.1371/journal.pone.0150184

Bryan G.W.. Waldichuk M., Pentreath R.J., et al. 1979. Bioaccumulation of marine pollutants [and Discussion]. Philos. Trans. R. Soc. B Biol. Sci. 286: 483-505.

Caetano M., Vale C., Bebianno M. 2002. Distribution of Fe, Mn, Cu and $\mathrm{Cd}$ in upper sediments and sediments-trap material of Ria Formosa (Portugal). J. Coast. Res. 36: 118-123.

Caetano M., Madureira M.J., Vale C. 2007. Exchange of Cu and Cd across the sediment-water interface in intertidal mud flats from Ria Formosa (Portugal). Hydrobiologia 587: 147-155. https://doi.org/10.1007/s10750-007-0673-y

Caetano M., Vale C. Anes B., et al. 2013. The Condor seamount at Mid-Atlantic Ridge as a supplementary source of trace and rare earth elements to the sediments. Deep Sea Res. Part II Top. Stud. Oceanogr. 98: 24-37. https://doi.org/10.1016/j.dsr2.2013.01.009

Capuzzo J.M., Moore M.N., Widdows J. 1988. Effects of toxic chemicals in the marine environment: predictions of impacts from laboratory studies. Aquat. Toxicol. 11: 303-311. https://doi.org/10.1016/0166-445X(88)90080-X

Cooper S., Bonneris E., Michaud A., et al. 2013. Influence of a stepchange in metal exposure $(\mathrm{Cd}, \mathrm{Cu}, \mathrm{Zn})$ on metal accumulation and subcellular partitioning in a freshwater bivalve, Pyganodon grandis. A long-term transplantation experiment between lakes with contrasting ambient metal levels. Aquat. Toxicol. 132-133: 73-83.

https://doi.org/10.1016/j.aquatox.2013.01.021

Cortesão C., Mendes R., Vale C. 1986. Metais pesados em bivalves e sedimentos na Ria Formosa, Algarve. Bol. Inst. Nac. Investig. das pescas 14: 3-28

Costanza R., D'Arge R., Groot R. de, et al. 1997. The value of the world's ecosystem services and natural capital. Nature 387: 253-260. https://doi.org/10.1038/387253a0

Cravo A., Pereira C., Gomes T., et al. 2012. A multibiomarker approach in the clam Ruditapes decussatus. to assess the impact of pollution in the Ria Formosa lagoon, South Coast of Portugal. Mar. Environ. Res. 75: 23-34. https://doi.org/10.1016/j.marenvres.2011.09.012

Cravo A., Cardeira S., Pereira C., et al. 2014. Exchanges of nutrients and chlorophyll $a$ through two inlets of Ria Formosa, South of Portugal, during coastal upwelling events. J. Sea Res. 93: 63-74. https://doi.org/10.1016/j.seares.2014.04.004

Cunha A.H., Santos R.P., Gaspar A.P., et al. 2005. Seagrass landscape-scale changes in response to disturbance created by the dynamics of barrier-islands: A case study from Ria Formosa (Southern Portugal). Estuar. Coast. Shelf Sci. 64: 636-644. https://doi.org/10.1016/j.ecss.2005.03.018

Delgado M., Pérez-Camacho A. 2005. Histological study of the gonadal development of Ruditapes decussatus (L.) (Mollusca: Bivalvia) and its relationship with available food. Sci. Mar. 69: 87-97. https://doi.org/10.3989/scimar.2005.69n187

DGRM 2013. Recursos da Pesca. Direcção Geral das Pescas e Aquicultura. Série estatística 201122 A-B, 181 pp.

EC 2001. Commission regulation (EC) no. 466/2001 of 8 March 2001 setting maximum levels for certain contaminants in foodstuffs, Official Journal of the European Communities. Brussels, L77.

Falcão M., Vale C. 1990. Study of the Ria Formosa ecosystem: benthic nutrient remineralization and tidal variability of nutrients in the water. Hydrobiologia 207: 137-146. https://doi.org/10.1007/BF00041450

Falcão M., Vale C. 1998. Sediment-water exchanges of ammonium and phosphate in intertidal and subtidal areas of a mesotidal coastal lagoon (Ria Formosa). Hydrobiologia 374: 193-201. https://doi.org/10.1023/A:1017083724636

Falcão M., Caetano M., Serpa D., et al. 2006. Effects of infauna harvesting on tidal flats of a coastal lagoon (Ria Formosa, Portugal): Implications on phosphorus dynamics. Mar. Environ. Res. 61: 136-148. https://doi.org/10.1016/j.marenvres.2005.08.002

Folch J., Lees M., Sloane-Stanley G. 1957. A simple method for the isolation and purification of total lipids from animal tissues. J. Biol. Chem. 226: 497-509.

Folk R.L., Ward W.C. 1957. Brazos River Bar: A study in the significance of grain size parameters. J. Sediment. Petrol. 27: 3-26. https://doi.org/10.1306/74D70646-2B21-11D7$8648000102 \mathrm{C} 1865 \mathrm{D}$

Gauthier-Clerc S., Pellerin J., Blaise C., et al. 2002. Delayed gametogenesis of Mya arenaria in the Saguenay fjord (Canada): a consequence of endocrine disruptors? Comp. Biochem. Physiol. Part C Toxicol. Pharmacol. 131: 457-467. https://doi.org/10.1016/S1532-0456(02)00041-8

Guimarães M.H.M.E., Cunha A.H., Nzinga R.L., et al. 2012. The distribution of seagrass (Zostera noltii) in the Ria Formosa lagoon system and the implications of clam farming on its conservation. J. Nat. Conserv. 20: 30-40. https://doi.org/10.1016/j.jnc.2011.07.005

Gustafson L.L., Stoskopf M.K., Bogan A.E., et al. 2005. Evaluation of a nonlethal technique for hemolymph collection in Elliptio complanata, a freshwater bivalve (Mollusca: Unionidae). Dis. Aquat. Organ. 65: 159-165. https://doi.org/10.3354/dao065159

Hamza-Chaffai A. 2014. Usefulness of bioindicators and biomarkers in pollution biomonitoring. Int. J. Biotechnol. Wellness Ind. 3: 19-26. https://doi.org/10.6000/1927-3037.2014.03.01.4

Ivanina A.V, Beniash E., Etzkorn M., et al. 2013. Short-term acute hypercapnia affects cellular responses to trace metals in the hard clams Mercenaria mercenaria. Aquat. Toxicol. 140-141: 123-133.

https://doi.org/10.1016/j.aquatox.2013.05.019

Libes S.M. 1992. An Introduction to Marine Biogeochemistry. New 
York, John Wiley and Sons, 734 pp.

Lima M.I.P. de, Santo F.E., Ramos A.M., et al. 2013. Recent changes in daily precipitation and surface air temperature extremes in mainland Portugal, in the period 1941-2007. Atmos. Res. 127: 195-209.

https://doi.org/10.1016/j.atmosres.2012.10.001

Luna-Acosta A., Bustamante P., Budzinski H., et al. 2015. Persistent organic pollutants in a marine bivalve on the Marennes-Oléron Bay and the Gironde Estuary (French Atlantic Coast) - part 2: potential biological effects. Sci. Total Environ. 514: 511-522. https://doi.org/10.1016/j.scitotenv.2014.10.050

Lushchak V.I. 2011. Environmentally induced oxidative stress in aquatic animals. Aquat. Toxicol. 101: 13-30. https://doi.org/10.1016/j.aquatox.2010.10.006

Mantel L.H., Farmer L.L. 1983. Internal Anatomy and Physiological Regulation. In: Mantel L.H. (ed.), The Biology of Crustacea, vol. 5. Academic Press, New York, pp. 54-161.

Marsh J.B., Weinstein D.B. 1966. Simple charring method for determination of lipids. J. Lipid Res. 7: 574-576.

Matias D., Joaquim S., Ramos M., et al. 2011. Biochemical compounds' dynamics during larval development of the carpet-shell clam Ruditapes decussatus (Linnaeus, 1758): Effects of monospecific diets and starvation. Helgol. Mar. Res. 65: 369-379. https://doi.org/10.1007/s10152-010-0230-3

Matias D., Joaquim S., Matias A.M., et al. 2013. The reproductive cycle of the European clam Ruditapes decussatus (L., 1758) in two Portuguese populations: Implications for management and aquaculture programs. Aquaculture 406-407: 52-61. https://doi.org/10.1016/j.aquaculture.2013.04.030

McFarland K., Divine J., Volety A. 2011. Influence of acute change salinity on osmolarity of hemolymph in the green mussel, Perna viridis, and the eastern oyster, Crassostrea virginica. J. Shellfish Res. 30: 532

Mil-Homens M., Vale C., Raimundo J., et al. 2014. Major factors influencing the elemental composition of surface estuarine sediments: The case of 15 estuaries in Portugal. Mar. Pollut. Bull. 84: $135-146$. https://doi.org/10.1016/j.marpolbul.2014.05.026

Mudge S.M., Bebianno M.J. 1997. Sewage contamination following an accidental spillage in the Ria Formosa, Portugal. Mar. Pollut. Bull. 34: 163-170. https://doi.org/10.1016/S0025-326X(96)00082-3

Newton A., Mudge S.M. 2003. Temperature and salinity regimes in a shallow, mesotidal lagoon, the Ria Formosa, Portugal. Estuar. Coast. Shelf Sci. 57: 73-85.

Newton A., Icely J.D., Falcão M., et al. 2003. Evaluation of eutrophication in the Ria Formosa coastal lagoon, Portugal. Cont. Shelf Res. 23: 1945-1961. https://doi.org/10.1016/j.csr.2003.06.008

Nicholson S., Lam P.K.S. 2005. Pollution monitoring in Southeast Asia using biomarkers in the mytilid mussel Perna viridis (Mytilidae: Bivalvia). Environ. Int. 31: 121-132. https://doi.org/10.1016/j.envint.2004.05.007

Nobre A.M., Ferreira J.G., Newton A., et al. 2005. Management of coastal eutrophication: Integration of field data, ecosystem-scale simulations and screening models. J. Mar. Syst. 56: 375-390. https://doi.org/10.1016/j.jmarsys.2005.03.003

Pacheco L., Vieira A., Ravasco J. 1989. Crescimento e reprodução de Ruditapes decussatus na Ria Formosa (Sul de Portugal). Bentos 6: 129-136.

Raimundo J., Vale C. 2008. Partitioning of Fe, Cu, Zn, Cd, and $\mathrm{Pb}$ concentrations among eleven tissues of Octopus vulgaris from the Portuguese coast. Cien. Mar. 34: 297-305.

Raimundo J., Vale C., Caetano M., et al. 2013. Natural trace element enrichment in fishes from a volcanic and tectonically active region (Azores archipelago). Deep Sea Res. Part II Top. Stud. Oceanogr. 98: 137-147. https://doi.org/10.1016/j.dsr2.2013.02.009

Reinfelder J.R., Fisher N.S., Luoma S.N., et al. 1998. Trace element trophic transfer in aquatic organisms: A critique of the kinetic model approach. Sci. Total Environ. 219: 117-135. https://doi.org/10.1016/S0048-9697(98)00225-3

Serafim M.A., Bebianno M.J. 2001. Variation of metallothionein and metal concentrations in the digestive gland of the clam $R u$ ditapes decussatus: sex and seasonal effects. Environ. Toxicol. Chem. 20: 544-552. https://doi.org/10.1002/etc.5620200313

Shakir F.K., Audilet D., Drake A.J., et al. 1994. A rapid protein determination by modification of the Lowry procedure. Anal. Biochem. 216: 232-233 https://doi.org/10.1006/abio.1994.1031

Simões M.de L.S., Vaz M.C.T.A., Silva J.J.R.F. da 1981. Stability constants of chloro-complexes of cadmium(ii) in sea-water medium. Talanta 28: 237-240. https://doi.org/10.1016/0039-9140(81)80047-1

Soares P.M.M., Cardoso R.M., Ferreira J.J., et al. 2015. Climate change and the Portuguese precipitation: ENSEMBLES regional climate models results. Clim. Dyn. 45: 1771-1787. https://doi.org/10.1007/s00382-014-2432-x

Vila-Concejo A., Matias A., Ferreira Ó., et al. 2002. Recent evolution of the natural inlets of a barrier island system in southern Portugal. J. Coast. Res. 752: 741-752.

Viles F.J., Silverman L. 1949. Determination of starch and cellulose with Anthrone. Anal. Chem. 21: 950-953 https://doi.org/10.1021/ac60032a019

Walne P.R. 1976. Experiments on the culture in the sea of the butterfish Venerupis decussata L. Aquaculture 8: 371-381. https://doi.org/10.1016/0044-8486(76)90119-8

Weinberg J.R., Leavitt D.F., Lancaster B.A, et al. 1997. Experimental field studies with Mya arenaria (Bivalvia) on the induction and effect of hematopoietic neoplasia. J. Invertebr. Pathol. 69: 183-194. https://doi.org/10.1006/jipa.1996.4641

Windom H.L., Schropp S.J., Calder F.D., et al. 1989. Natural trace metal concentrations in estuarine and coastal marine sediments of the southeastern United States. Environ. Sci. Technol. 23: 314-320. https://doi.org/10.1021/es00180a008

Yatoo M.I., Saxena A., Deepa P.M., et al. 2013. Role of trace elements in animals: a review. Vet. World 6: 963-967. https://doi.org/10.14202/vetworld.2013.963-967 